\title{
THE ALVEOLAR-ARTERIAL OXYGEN PRESSURE GRADIENT IN ANEMIA 1
}

\author{
By J. M. RYAN 2 AND J. B. HICKAM
}

(From the Department of Medicine, Duke University School of Medicine, Durham, N. C.)

(Submitted for publication August 31, 1951; accepted November 8, 1951)

\section{INTRODUCTION}

In anemia the oxygen-carrying capacity of the blood is reduced but it is generally believed that the resting arterial oxygen saturation is normal (1-5). Because of the characteristics of the oxyhemoglobin dissociation curve, an appreciable degree of reduction in arterial oxygen tension below the normal level might be present and not be detected by measuring the per cent of arterial oxygen saturation from oxygen contents of arterial and saturated bloods. Within recent years more sensitive techniques have been developed for measuring arterial $\mathrm{pO}_{2}$. It is possible to measure the arterial oxygen tension directly and to estimate the difference between this and the alveolar oxygen tension, the so-called alveolararterial oxygen tension gradient $(6,7)$. The demonstration that breathing under certain conditions is significantly influenced by changes in oxygen tension which are difficult to estimate by the older methods of measuring per cent arterial oxygen saturation has stimulated our interest in the influence of arterial oxygenation on respiration in disease. The present report deals with the application of these more sensitive techniques to the problem of arterial oxygenation in anemia.

\section{METHODS}

Observations were made on 10 anemic (Hgb. 2.0-8.9 grams \%) and 11 control subjects ( $\mathrm{Hgb}$. 10.5-14.9 grams \%). There was no evidence of pulmonary disease or congestive heart failure in any subject, as judged by history and by physical and roentgen examination. Five of the control subjects (K. W., V. P., S. V., G. S., and W. A.) were medical students; the remainder were hospital patients.

Expired air was collected in Douglas bags. Several minutes were allowed to accustom the subject to the

1 This work was supported by grants from the Life Insurance Medical Research Fund and the Anna H. Hanes Memorial Fund.

2 Present address : Department of Medicine, Ohio State University, Columbus, Ohio. respiratory apparatus, after which two collections of approximately three minutes each were made. The first of these served as a check to insure that minute volume and respiratory quotient were not fluctuating widely. During the second collection, arterial blood was slowly drawn over a one to two minute period through an inlying needle previously placed in the brachial artery. Where a reduced oxygen mixture was inspired $(14.7 \%$ $\mathrm{O}_{2}, 85.3 \% \mathrm{~N}_{2}$ ), the subject breathed this mixture for at least 15 minutes before the final air collection was begun. Procedures were carried out at an ambient temperature of $23 \pm 1.5^{\circ} \mathrm{C}$. and a barometric pressure of $748 \pm 5 \mathrm{~mm}$. $\mathrm{Hg}$.

"Direct" blood $\mathrm{O}_{2}$ and $\mathrm{CO}_{2}$ tensions were measured by the method of Riley, Proemmel, and Franke (6), using some of the modifications suggested by Lambertsen and Bunce (8). The accuracy of this method in our hands was checked against blood which had been brought to known gas tensions by equilibration in a tonometer at $37^{\circ} \mathrm{C}$. There were 10 such samples, with hemoglobin contents ranging from 2.0 to 15.0 grams $\%, \mathrm{CO}_{2}$ tensions from 34 to $82 \mathrm{~mm}$. $\mathrm{Hg}$, and $\mathrm{O}_{2}$ tensions from 55 to $106 \mathrm{~mm} . \mathrm{Hg}$. The mean deviations of measured tensions from actual tensions were, for $\mathrm{CO}_{2},-1.8 \pm 0.9 \mathrm{~mm}$. $\mathrm{Hg}$ (S.D. $\pm 2.8 \mathrm{~mm}$. $\mathrm{Hg}$ ) ; and, for $\mathrm{O}_{2}, 0.2 \pm 0.7 \mathrm{~mm}$. $\mathrm{Hg}$ (S.D. $\pm 2.3 \mathrm{~mm} . \mathrm{Hg}$ ). "Indirect" $\mathrm{CO}_{2}$ tensions were also measured in all subjects by methods previously described (9). The mean "indirect" $\mathrm{CO}_{2}$ tension exceeded the "direct" tension by $1.3 \pm 0.9 \mathrm{~mm}$. Hg. (S.D. \pm 4.5 $\mathrm{mm} . \mathrm{Hg}$ ). The blood $\mathrm{CO}_{2}$ tensions reported in Tables I and II represent an average between "direct" and "indirect" determinations. Arterial blood oxygen saturation was determined by a spectrophotometric method (10). "Indirect" $\mathrm{O}_{2}$ tensions, obtained by referring per cent saturation values to standard oxyhemoglobin dissociation curves, agreed quite satisfactorily with "direct" $\mathrm{O}_{2}$ tensions in subjects breathing low oxygen mixtures (mean algebraic difference, "direct" minus "indirect" $\mathrm{pO}_{2}$ : $-1.0 \mathrm{~mm}$. $\mathrm{Hg}$; mean absolute difference: $5 \mathrm{~mm}$. $\mathbf{H g}$ ).

"Ideal" alveolar air was determined by the graphic method of Riley and Cournand (7). Alveolar $\mathrm{O}_{2}$ tensions by this method agreed quite closely with tensions calculated by the "alveolar" equation (11) during the breathing of both air and the reduced oxygen mixture in all cases, and no substantial difference would result, in these subjects, from the use of the latter expression instead of the former.

\section{RESULTS}

The pertinent data from the control group are presented in Table I and that from the group of 
TABLE I

Alveolar and arterial gas tensions in control subjects

\begin{tabular}{|c|c|c|c|c|c|}
\hline Subject & $\underset{\text { (Gms. \%) }}{\text { Hgb. }}$ & $\begin{array}{c}\text { "Ideal" } \\
\text { alveolar } \\
O_{2} \\
\text { tension } \\
\left.\text { (mm. } H_{g}\right)\end{array}$ & $\begin{array}{c}\text { Arterial } \\
\text { O }_{2} \\
\text { tension } \\
\left(\boldsymbol{m m} . \mathrm{Hg}_{\mathrm{g}}\right)\end{array}$ & $\left|\begin{array}{c}\text { Arterial } \\
\mathrm{CO}_{\mathbf{2}} \\
\text { tension } \\
\left(\mathrm{mm} . \mathrm{Hg}_{\mathbf{g}}\right)\end{array}\right|$ & $\begin{array}{c}\text { Alveolar- } \\
\text { arterial } \\
O_{2} \\
\text { tension } \\
\text { gradient } \\
(\mathrm{mm} . \mathrm{Bg})\end{array}$ \\
\hline $\begin{array}{l}\text { K. W., } 23 \mathrm{M} \\
\text { V. P., } 27 \mathrm{M} \\
\text { D. C., } 47 \mathrm{M} \\
\text { S. H., } 57 \mathrm{~F} \\
\text { S. V., } 23 \mathrm{M} \\
\text { G. S., } 23 \mathrm{M} \\
\text { W. A., } 25 \mathrm{M} \\
\text { P. D., } 42 \mathrm{~F} \\
\text { J. H., 39 M } \\
\text { W. P. } 53 \mathrm{M} \\
\text { L. G., } 62 \mathrm{~F}\end{array}$ & $\begin{array}{l}13.6 \\
13.7 \\
13.8 \\
11.4 \\
13.7 \\
12.8 \\
12.6 \\
13.9 \\
13.9 \\
11.7 \\
10.5\end{array}$ & $\begin{array}{r}98.2 \\
98.6 \\
89.2 \\
104.1 \\
99.6 \\
100.1 \\
104.8 \\
100.0 \\
104.0 \\
92.0 \\
90.3\end{array}$ & $\begin{array}{r}104.0 \\
98.0 \\
99.0 \\
95.1 \\
98.7 \\
96.3 \\
97.5 \\
98.0 \\
94.7 \\
76.7 \\
81.0\end{array}$ & $\begin{array}{l}38.9 \\
39.0 \\
43.6 \\
32.4 \\
41.1 \\
42.9 \\
35.0 \\
39.4 \\
35.2 \\
38.8 \\
48.2\end{array}$ & $\begin{array}{r}-5.8 \\
-0.6 \\
-5.8 \\
9.0 \\
0.9 \\
3.8 \\
7.3 \\
2.0 \\
9.3 \\
15.3 \\
9.3\end{array}$ \\
\hline Mear & $12.9 \pm 0.4$ & $98.3 \pm 1.7$ & $94.1 \pm 2.4$ & $39.5 \pm 1.3$ & $4.2 \pm 2.0$ \\
\hline
\end{tabular}

anemic subjects in Table II. The mean difference between alveolar and arterial oxygen tensions (A-A gradient) is $4.2 \pm 2.0 \mathrm{~mm}$. $\mathrm{Hg}$ for the control group and $20.5 \pm 4.6 \mathrm{~mm}$. $\mathrm{Hg}$ for the anemic group. The difference is quite significant $(p<.01)$. The alveolar oxygen tension is slightly higher and the $\mathrm{CO}_{2}$ tension slightly lower in the anemic than in the control group, but the differences are not significant. A significant dif-

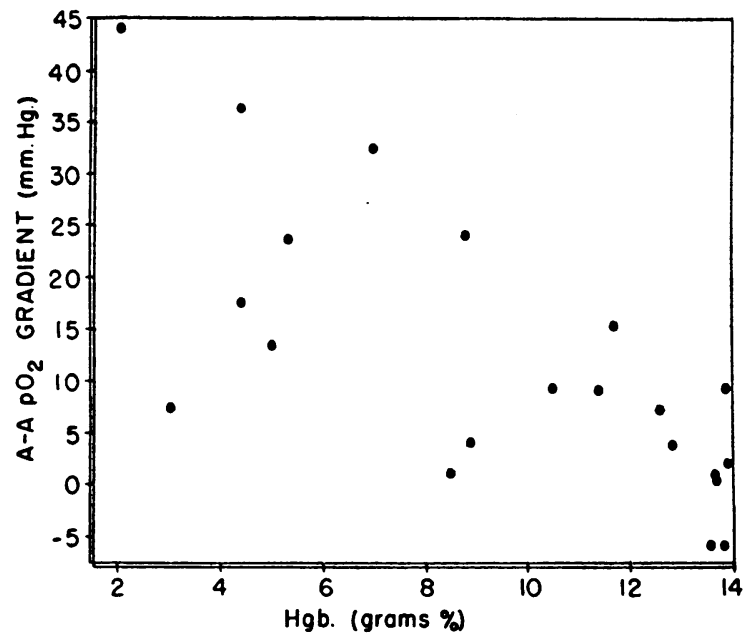

Fig. 1. Relation Between Hemoglobin and A-A $\mathrm{PO}_{2}$ Gradient in 21 Subjects

A negative correlation exists $(r=-.728)$.

ference $(p<.01)$ does exist, however, between the arterial oxygen tension of $94.1 \pm 2.4 \mathrm{~mm}$. $\mathrm{Hg}$ in the control group and that of $82.1 \pm 2.6 \mathrm{~mm}$. $\mathrm{Hg}$ in the anemic group.

TABLE II

Alveolar and arterial gas tensions in anemic subjects

\begin{tabular}{|c|c|c|c|c|c|c|c|c|c|c|c|}
\hline \multirow{2}{*}{ Subject } & \multirow[t]{2}{*}{ Comment } & \multicolumn{2}{|c|}{$\underset{\text { (Gms. \%) }}{\text { Hgb. }}$} & \multicolumn{2}{|c|}{$\begin{array}{l}\text { "Ideal" } \\
\text { alveolar } \\
\mathrm{O}_{2} \text { tension } \\
(\boldsymbol{m m} . \boldsymbol{H g})\end{array}$} & \multicolumn{2}{|c|}{$\begin{array}{c}\text { Arterial } \\
O_{2} \text { tension } \\
(\boldsymbol{m m} . \boldsymbol{H g})\end{array}$} & \multicolumn{2}{|c|}{$\begin{array}{c}\text { Arterial } \\
\mathrm{CO}_{2} \text { tension } \\
\left(m m . H_{g}\right)\end{array}$} & \multicolumn{2}{|c|}{$\begin{array}{c}\text { Alveolar- } \\
\text { arterial } \mathrm{O}_{2} \\
\text { tension gradient } \\
(\mathrm{mm} . \mathrm{Hg})\end{array}$} \\
\hline & & Air & $\begin{array}{l}14.7 \\
\% \mathrm{O}_{2}\end{array}$ & Air & $\underset{\%}{14.7} \mathrm{O}_{2}$ & Air & $\begin{array}{l}14.7 \\
\% \mathrm{O}_{2}\end{array}$ & Air & $\begin{array}{l}14.7 \\
\% \mathrm{O}_{2}\end{array}$ & Air & ${ }_{\%}^{14.7} \mathrm{O}_{2}$ \\
\hline $\begin{array}{l}\text { R. A., } 37 \mathrm{~F} \\
\text { J. C., } 52 \mathrm{M} \\
\text { J. C., } 38 \mathrm{M} \\
\text { E. H., } 57 \mathrm{~F} \\
\text { S. P., } 17 \mathrm{~F} \\
\text { W. P., } 53 \mathrm{M} \\
\text { A. P., } 48 \mathrm{M} \\
\text { E. R., } 62 \mathrm{~F} \\
\text { L. R., } 38 \mathrm{~F} \\
\text { S. T., } 50 \mathrm{~F}\end{array}$ & $\begin{array}{l}\text { Pernicious } \\
\text { anemia } \\
\text { Chronic } \\
\text { blood loss } \\
\text { Pernicious } \\
\text { anemia } \\
\text { Chronic } \\
\text { blood loss } \\
\text { Chronic } \\
\text { blood loss } \\
\text { Chronic } \\
\text { blood loss } \\
\text { Multiple } \\
\text { myeloma } \\
\text { Chronic } \\
\text { blood loss } \\
\text { Macrocytic } \\
\text { anemia } \\
\text { Chronic } \\
\text { blood loss }\end{array}$ & $\begin{array}{l}8.8 \\
3.0 \\
5.3 \\
2.0 \\
8.9 \\
4.4 \\
5.0 \\
7.0 \\
8.5 \\
4.4\end{array}$ & $\begin{array}{l}7.4 \\
8.7 \\
4.2\end{array}$ & $\begin{array}{r}110.5 \\
87.2 \\
108.5 \\
117.7 \\
97.7 \\
94.8 \\
95.6 \\
110.5 \\
96.4 \\
106.5\end{array}$ & $\begin{array}{l}59.8 \\
54.5 \\
54.7\end{array}$ & $\begin{array}{l}86.4 \\
79.7 \\
84.7 \\
73.5 \\
93.7 \\
77.2 \\
82.1 \\
78.0 \\
95.3 \\
70.1\end{array}$ & $\begin{array}{l}58.8 \\
58.5 \\
49.2\end{array}$ & $\begin{array}{l}33.2 \\
42.9 \\
29.4 \\
24.5 \\
40.0 \\
42.7 \\
45.4 \\
30.1 \\
44.0 \\
40.8\end{array}$ & $\begin{array}{l}31.0 \\
41.8 \\
39.9\end{array}$ & $\begin{array}{r}24.1 \\
7.5 \\
23.8 \\
44.2 \\
4.0 \\
17.6 \\
13.5 \\
32.5 \\
1.1 \\
36.4\end{array}$ & $\begin{array}{r}-3.1 \\
-0.5 \\
1.0 \\
-4.0 \\
5.5\end{array}$ \\
\hline Mean & & $\begin{array}{l}5.7 \\
\pm \\
0.8\end{array}$ & & $\begin{array}{c}102.5 \\
\pm \\
3.0\end{array}$ & $\begin{array}{l}56.9 \\
\pm \\
3.6\end{array}$ & $\begin{array}{c}82.1 \\
\pm \\
2.6\end{array}$ & $\begin{array}{c}53.6 \\
\pm \\
1.6\end{array}$ & $\begin{array}{c}37.3 \\
\pm \\
2.3\end{array}$ & $\begin{array}{c}37.2 \\
\pm \\
2.0\end{array}$ & $\begin{array}{c}20.5 \\
\pm \\
4.6\end{array}$ & $\begin{array}{l}3.3 \\
\pm \\
4.0\end{array}$ \\
\hline
\end{tabular}

* Same patient as W. P. in Table I. 
In Figure 1 the relation between $\mathrm{A}-\mathrm{A}$ gradient and hemoglobin concentration is plotted for all subjects of both groups. There is an apparent negative correlation between the two measurements which proves to be significant $(r=-.728$, $\mathrm{p}<.01)$. The figure indicates a fairly marked tendency for the gradient to scatter more as the hemoglobin concentration is reduced.

In seven anemic subjects the A-A gradient was measured during the inhalation of $14.7 \% \quad \mathrm{O}_{2}$. In all cases but one there was a reduction of the gradient. The mean gradient on the low $\mathrm{O}_{2}$ mixture was $3.3 \pm 4.0 \mathrm{~mm}$. $\mathrm{Hg}$. This is a significant decrease ( $p$ approximately .02).

The occurrence of small negative gradients on the low $\mathrm{O}_{2}$ mixture and in the control group on air is evidently owing to experimental error. Judged by the validation procedure described in the preceding section, the error is small, and it should apply equally to both anemic and control groups.

\section{DISCUSSION}

Despite equivalent alveolar ventilation, the arterial blood $\mathrm{O}_{2}$ tension is significantly lower in the anemic than in the control groups, and the A-A gradient is significantly greater in the anemic group. There is some evidence which bears on the cause of this. Calculations based on principles outlined by Bohr (12) indicate that anemia per se should not adversely affect the attainment of equilibrium between the oxygen tensions of alveolar air and pulmonary capillary blood. Lilienthal, Riley, Proemmel, and Franke (13) have pointed out that inhalation of a low oxygen mixture will increase a gradient which depends upon impairment to oxygen diffusion across the alveolar-capillary "membrane," and will decrease a gradient which depends upon admixture of venous blood with oxygenated blood. The effect of a low oxygen mixture in the anemic group suggests that the increased gradient in this case results from venous admixture, rather than impairment of alveolar-capillary diffusion, such as might be caused by pulmonary edema.

Venous admixture to oxygenated blood may occur through such channels as Thebesian veins and bronchial veins which connect with pulmonary veins, or may result from blood flow through imperfectly aerated regions of the lung $(13,14)$.
It also seems possible that some oxygen is lost from blood in the left ventricular cavity by diffusion across the endocardium into the left ventricular muscle. A very large difference in $\mathrm{O}_{2}$ tension normally exists between arterial blood and heart muscle, and the $\mathrm{O}_{2}$ tension of ventricular muscle is even lower than normal in anemia (15).

In anemia the per cent oxygen saturation of mixed venous blood is usually decreased (16). The effect of venous admixture in lowering arterial oxygen tension becomes greater as the per cent oxygen saturation of the venous blood is reduced. The question arises as to whether the increased A-A gradient of the anemic subject can be accounted for on the basis of admixture of a normal proportion of venous blood. Enough information exists to allow an estimate. The per cent of venous admixture can be expressed as the ratio $\frac{X-A}{X-V}$, where $X$ is the blood oxygen content corresponding to the oxygen tension of alveolar air, $\mathrm{A}$ is the arterial content, and $\mathrm{V}$ is the venous content ( 7$)$. In normal subjects $V$ can be estimated by using an arbitrary $\mathrm{A}-\mathrm{V} \mathrm{O}_{2}$ difference of 4.3 vol. $\%$, without much risk to the calculation. With the present anemic subjects, an $\mathrm{A}-\mathrm{V}$ difference was assigned to each subject according to hemoglobin concentration, using a regression line calculated from the data of Brannon, Merrill, Warren, and Stead (16). For uniformity, oxygen contents of "pulmonary capillary blood" ("X") and arterial blood were estimated from the corresponding oxygen tensions, using standard dissociation curves, and taking due account of the presence of dissolved oxygen. The result of these calculations in the anemic group is a mean venous admixture of $6.6 \pm 1.4 \%$ of the total cardiac output. This is in the same order of magnitude as the value of $4.2 \%$ found by Riley and Cournand for eight normal subjects, but is about three times the proportion found in our control group. The data on which the proportions of venous admixture are estimated are not sufficiently exact in this case to allow more than the conclusion that the A-A gradient of anemia can depend upon "venous admixture" in normal or near-normal quantities.

If the per cent oxygen saturation of venous blood were still further reduced, the A-A gradient would be further increased. Himwich and Loebel 
(2) found a decrease in the arterial blood oxygen saturation of three anemic subjects during exercise. The methods used were stated to be susceptible to considerable error in anemic subjects, but the present results provide inferential support for this finding. Such a fall in arterial oxygen tension during exercise might contribute significantly to the exertional dyspnea which characterizes anemia $(3,8)$. It is not easy to account for this dyspnea on the basis of decrease in maximum breathing capacity or increase in breathing requirement by demonstrated stimuli acting along well-recognized pathways. The subject deserves further attention.

It has been suggested that a deficiency of carbonic anhydrase in anemic subjects might interfere with elimination of carbon dioxide in the lungs (3). In the present subjects, who were at rest, the arterial carbon dioxide tension was within the normal range, but the possibility remains that such an effect might become evident during exercise, when the rate of excretion of carbon dioxide is increased.

\section{SUMMARY AND CONCLUSIONS}

1. The arterial oxygen tension and alveolararterial oxygen tension gradient have been measured in 10 anemic and 11 normal subjects.

2. The anemic group had a significantly lower arterial oxygen tension and higher A-A gradient than the normal group. Taking all subjects together, there was a significant negative correlation between hemoglobin concentration and A-A gradient.

3. It appears possible to account for this effect on the basis of "venous admixture" in normal or near-normal quantities.

\section{REFERENCES}

1. Harrop, G. A., Jr., The oxygen and carbon dioxide content of arterial and of venous blood in normal individuals and in patients with anemia and heart disease. J. Exper. Med., 1919, 30, 241.

2. Himwich, H. E., and Loebel, R. O., The oxygen satu- ration of hemoglobin in the arterial blood of exercising patients. J. Clin. Invest., 1927, 5, 113.

3. Blumgart, H. L., and Altschule, M. D., Clinical significance of cardiac and respiratory adjustments in chronic anemia. Blood, 1948, 3, 329.

4. Best, C. H., and Taylor, N. B., The Physiological Basis of Medical Practice. The Williams and Wilkins Company, Baltimore, 1945, Fourth Edition, p. 356.

5. Mason, M. F., Wintrobe, M. M., and Harrison, T. R., Anoxia, Cyanosis, and Polycythemia, in Harrison, T. R., Principles of Internal Medicine. The Blakiston Co., Philadelphia, 1950, p. 132.

6. Riley, R. L., Proemmel, D. D., and Franke, R. E., A direct method for determination of oxygen and carbon dioxide tensions in blood. J. Biol. Chem., 1945, 161, 621.

7. Riley, R. L., and Cournand, A., "Ideal" alveolar air and the analysis of ventilation-perfusion relationships in the lungs. J. Appl. Physiol., 1949, 1, 825.

8. Lambertsen, C. J., and Bunce, P. L. Cited by Comroe, J. H., Jr., Methods in Medical Research. The Year Book Publishers, Inc., Chicago, 1950, Vol. II, p. 162.

9. Hickam, J. B., Pryor, W. W., Page, E. B., and Atwell, R. J., Respiratory regulation during exercise in unconditioned subjects. J. Clin. Invest., 1951, 30, 503.

10. Hickam, J. B., and Frayser, R., Spectrophotometric determination of blood oxygen. J. Biol. Chem., 1949, 180, 457.

11. Standardization of definitions and symbols in respiratory physiology. Federation Proc., 1950, 9, 602.

12. Bohr, C., Uber die spezifische Tätigkeit der Lungen bei der respiratorischen Gasaufnahme und ihr Verhalten zu der durch die Alveolarwand stattfindenden Gasdiffusion. Skandinav. Arch. f. Physiol., 1909, 22, 221.

13. Lilienthal, J. L., Jr., Riley, R. L., Proemmel, D. D., and Franke, R. E., An experimental analysis in man of the oxygen pressure gradient from alveolar air to arterial blood during rest and exercise at sea level and at altitude. Am. J. Physiol., 1946, 147, 199.

14. Riley, R. L., Pulmonary gas exchange. Am. J. Med., 1951, 10, 210.

15. Bing, R. J., and Daley, R., Behavior of the myocardium in health and disease as studied by coronary sinus catheterization. Am. J. Med., 1951, 10, 711.

16. Brannon, E. S., Merrill, A. J., Warren, J. V., and Stead, E. A., Jr., The cardiac output in patients with chronic anemia as measured by the technique of right atrial catheterization. J. Clin. Invest., 1945, $24,332$. 